\title{
Constraints and Suggestions Faced by Goat Rearing Farmers in Mirzapur District of Uttar Pradesh, India
}

\author{
Manoj Kumar Singh ${ }^{1 *}$, Ramjee Gupta ${ }^{1}$, P. K. Upadhyay ${ }^{1}$, Dinesh Singh ${ }^{1}$, \\ Deepak Singh ${ }^{1}$ and Pankaj $\operatorname{Rav}^{2}$ \\ ${ }^{1}$ Department of Animal Husbandry \& Dairying, C. S. Azad University of Agriculture and \\ Technology Kanpur India -208 002, India \\ ${ }^{2}$ Department of Agriculture Extension, B. H. U. Varanasi, India
}

*Corresponding author

A B S T R A C T

Keywords

Constraints and Suggestions

Article Info

Accepted:

08 January 2020

Available Online:

10 February 2020
The domestic goat Capra hircus is one of the oldest domesticated farm animals. It provides multiple products like meat (chevon), milk, skin, fiber and manure. They survive efficiently on available thorny shrubs and trees in adverse harsh environment in low fertile lands where no other crops can be grown. In India, goats are kept as a source of livelihood and additional income as well as insurance against natural or manmade disasters. The constraints have been assessed on the basis of interview schedule conducted on 125 farmers in Mirzapur district of Uttar Pradesh.

\section{Introduction}

Goats play an important role in the rural economy at national level. More than 70 percent of the landless agricultural labourers and marginal and small farmers of the rural India rear them. The socio-economic value of goat rearing as compared to other livestock species has been immense, for the poor farmers. The low input, high fecundity, easy marketing and unprejudiced social acceptance of their products are few of many advantages of this enterprise that provides assured higher income. Goats are also among the main meatproducing animals in India, whose meat (chevon) is readily preferred irrespective of caste, creed and religion. They produce a variety of products, mainly meat, milk, skin, fiber and manure. The goats are particularly useful in the semiarid, arid and mountainous regions, where they can sustain on sparse vegetation and extreme climatic conditions.

Further, wherever irrigation facilities are poor, one can generally find large areas of waste and other common property land; on which the small ruminants of rural resourcepoor households can survive. A major part of their fodder requirement is met through such waste and other common property lands. It 
has been argued that these rural households have often developed highly efficient agricultural and livelihood systems that make the most rational and conservative use of the scarce resources available to them (Barbier, 1989). The rural poor who cannot afford to maintain a cow or a buffalo find goat/ sheep as the best alternative source of supplementary income and milk.

This is one reason why poor rural households maintain a few number of goats. Unlike a cow or buffalo, a few goats can be maintained easily and can be easily sold in the years of drought. Therefore this sector assumes critical importance in rain fed areas, high altitudes as well as in wasteland and fragile zones having low agricultural productivity. However the productivity of goats under the prevailing extensive production system is very low. Hence it important to search the major hurdles in goat rearing with following objectives: To study suggestions and constraints of goat faced by farmers.

\section{Materials and Methods}

\section{Sampling plan of the study}

This study was conducted in Mirzapur district. This has 12 development block out of which 5 was selected on the basis hilly region after this each block was divided on two strata and 5-6 villages were selected from each randomly out of 25 villages from the blocks and 5 farmers have been selected from each village on randomly basis then total farmers interviewed.

\section{Selection of variables}

Selection of variables two variables viz. suggestions and constraints which constituted the socio-economic profile of a farmer were selected purposively to assess the suggestions and constraints faced by goat rearing.

\section{Tools and techniques of data collection}

A pre-tested structured interview schedule was prepared. Data was collected by personal interview method.

\section{Statistical tools used}

Simple statistical tools like frequency and percentage were used for interpretation of data. The respondents on the basis of frequency and percentage of the total score.

\section{Results and Discussion}

\section{Constraints and Suggestions of goat}

\section{Constraints}

Constraints faced by farmers Table 1 shows that the this study that lack of credit 86.40 per cent, lack of extension support 74.40 per cent, lack of government support 74.40 Per cent, lack of capital 72.08 per cent, breeds 71.20 per cent, inadequate veterinary service 71.20 per cent, feeds and fodder 70.40 per cent, housing facility 65.60 per cent, diseases and parasites 63.20 per cent, low price of milk 58.40 per cent, lack of scientific knowledge 56.80 per cent, drought 55.20 per cent, market 23.20 per cent and theft 21.60 per cent were the major constraints asked for goat farmers. Similar with the constraints by the Singh et al., (2013) observed that the in Hamirpur and Mahoba districts, respectively.

Tanwar (2011) found feeding constraints in Rajasthan. Shah et al., (2015) poor veterinary infrastructure and services in Jammu and Kashmir, Similar findings were reported by Mohan et al., (2009) in Mathura and Gatew et al., (2015) in Ethiopia.

Mortality and morbidity losses are a major constraint in the traditional flocks (Kumar, 2003). Lawania and Gupta (2015) economic 
problem and less profit faced by the tribal farmers in Rajasthan, Baruwa (2013) for financial problem, Okewu and Iheanacho (2015) in the Nigeria that major constraints for goat marketing, Adefemi (2014) 87.2 Per cent finance the enterprise in Nigeria. Jana $e t$ al., (2014) pure breed buck were Burdwan district of West Bengal.

Table.1 Major constraints of goat production

\begin{tabular}{|c|c|c|c|}
\hline SI. N. & Constraints & Frequency & Percentage \\
\hline 1 & Diseases and parasites & 79 & 63.20 \\
\hline 2 & Feeds and Fodder & 88 & 70.40 \\
\hline 3 & Drought & 69 & 55.20 \\
\hline 4 & Lack of scientific knowledge & 71 & 56.80 \\
\hline 5 & Lack of extension support & 93 & 74.40 \\
\hline 6 & Lack of capital & 91 & 72.80 \\
\hline 7 & Market & 29 & 23.20 \\
\hline 8 & Theft & 27 & 21.60 \\
\hline 9 & Lack of government support & 93 & 74.40 \\
\hline 10 & Breeds & 89 & 71.20 \\
\hline 11 & Housing facility & 82 & 65.60 \\
\hline 12 & Lack of credit & 89 & 86.40 \\
\hline 13 & Inadequate veterinary service & 73 & 71.20 \\
\hline 14 & Low price of milk & 58.40 \\
\hline
\end{tabular}

Table.2 Farmers Suggestions for Improve of Goat Production

\begin{tabular}{|c|c|c|c|}
\hline S. No. & Constraints & Frequency & Percentage \\
\hline $\mathbf{1}$ & Development grazing land & 104 & 83.20 \\
\hline $\mathbf{2}$ & Provide veterinary facilities & 89 & 71.20 \\
\hline $\mathbf{3}$ & Availability of improved Breeds & 89 & 71.20 \\
\hline $\mathbf{4}$ & Provide adequate of extension service & 93 & 74.40 \\
\hline $\mathbf{5}$ & Better prices for improved goat products & 59 & 47.20 \\
\hline $\mathbf{6}$ & credit facility of low interest & 64 & 51.20 \\
\hline $\mathbf{7}$ & Provide breeding Bucks & 51 & 40.80 \\
\hline $\mathbf{8}$ & Develop milk marketing & 62 & 49.60 \\
\hline
\end{tabular}

\section{Suggestions}

Suggestion for improvement Table 2 shows that the goat farmers of the study area were asked to suggest some possible solutions to the problems such as development grazing land 83.20 per cent, provide veterinary facilities 74.40 per cent, availability of improved breeds 71.20 per cent, provide adequate of extension service 71.20 per cent, credit facility of low interest 51.20 per cent, better prices for improved goat products 47.20 per cent, develop milk marketing 46.67 per cent and provide breeding bucks 40.80 per cent. Similar with the suggestions by the Shah et al., (2015) for veterinary hospital and increase number of veterinary staff, Kumar (2012) reported that health care facility and regular vaccination camp, Barua et al., (2006) suggested that there should be establishment 
of veterinary call centres of livestock diseases, Chander and Rathod (2013) effective extension services and strengthening animal market, Sawal and Yadav (2006) protecting the common property of village for grazing, Meena and Mann (2006) improvement of common grassland, establishment of pasture and silvi-pasture system.

It can be seen from this study that were the many major constraints asked for goat farmers. The goat farmers of the study area were asked to suggest some possible solutions to the problems. Semi-intensive systems can be profitable at rural areas in Mirzapur. This study can be beneficial for those who are interested to establish goat farm in the rural areas in Mirzapur, which may help in improved economic condition and alleviating poverty.

The district's climatic conditions are highly suitable for the expansion of goat rearing further and there is a vast potential to increase its contribution by many fold to the district economy. Semi-intensive systems perform better than intensive and extensive system in Mirzapur District. The possible explanation for higher production and reproduction among semi-intensive systems was due to better feeding, proper grazing, control of mortality and diseases with better health care and good management practices followed by goat keepers. Profit from dairy goat enterprise is significantly higher in semi-intensive systems than intensive and extensive system. Relatively lower cost of goats farming was mainly due to higher production of milk and very short breeding interval and fast multiplication and early maturity of kids in case of semi-intensive systems as compared to other rearing system.

As extensive system goats did not receive any feed supplements, their growth were lower than in semi-intensive system goats and thus, these goats showed a lower body weight with advancement of age. The reason less respondent of intensive system or rearing might be the initial high cost involvement and lack of knowledge about scientific goat rearing.

\section{References}

Adefemi O J (2014) Structure and Performance of Goat Market in Oyo State, Nigeria, International Journal of Sales \& Marketing Management Research and Development 4-6, Dec, 1-10.

Barua S, Vaid R K, Kumar A and Vihan V S (2006) Role of veterinary service in commercial goat farming Proceedings of National workshop-cum-seminar on commercial goat and sheep farming and marketing: farmer industry research interface. pp. 231-32. 4-5 March Central Institute for Research on Goats, Makhdoom, Mathura, Uttar Pradesh.

Baruwa O I (2013) Empirical Analysis of Costs and Returns to Goat Production under Tropical Conditions, J. of Livestock Sci. 4:44-50.

Chander M and Rathod P K (2013) Investment in livestock extension activities by State Departments of Animal Husbandry (SDAH) in India: An appraisal. Indian Journal of Animal Sciences 83 (2): 185-89.

Gatew H, Hassen H, Kebede K, Haile A, Lôbo R N B, Yetayew A and Rischkowsky B (2015) Characterization of Indigenous Goat Populations in Selected Areas of Ethiopia, American-Eurasian Journal of Scientific Research 10 (5): 287-298.

Jana C, Rahman F H, Mondal S K, Singh A K (2014) Management practices and perceived constraints in goat rearing in Burdwan district of West Bengal. Indian 
Res. J. Ext. Edu., 14(2):107-110.

Kumar R (2012) Adoption and sustainability of goat heath technologies among farmer in different agro-climatic zones of Bihar, Ph.D. Thesis, IVRI, Izatnagar, India.

Kumar S, Vihan V S and Deoghare P R (2003) Economic implication of diseases in goats in India with reference to implementation of a health plan calendar. Small Ruminant Research, 47: 159-64.

Lawania P and Gupta S (2015) A Study on Constraints Encountered by the Tribal Livestock Farmers in Southern Rajasthan Advances in Social Research December, 1(1): 61-64

Meena L R and Mann J S (2006) Adopt fodder production technologies for commercial sheep and goat farming. Proceedings of National WorkshopCum-Seminar on Commercial Goat and Sheep Farming and Marketing: Farmer Industry Research Interface. pp. 22627. 4-5 March. Central Institute for Research on Goats, Makhdoom, Mathura, Uttar Pradesh.

Mohan B, Sagar R L and Singh K (2009) Factors Related to Promotion of Scientific Goat Farming. Indian Research Journal of Extension Education 9 (3): 47-50.

Okewu J and Iheanacho A C (2015) Profitability of Goat Marketing in Benue State, Nigeria: A Study of Selected Local Government Areas International Academic Journal of
Educational Research, 10:2, 54-74.

Sawal R K and Yadav S B S (2006) Marketing and economics of small ruminants for meat in Bikaner. Proceedings of National workshopcum-seminar on commercial goat and sheep farming and marketing: farmer industry research interface. Pp. 227-29. 4-5 March 2006. Central Institute for Research on Goats, Makhdoom, Mathura, Uttar Pradesh.

Shah I A, Hussain K and Shah M A (2015) Suggestions for Amelioration of Perceived Constraints in the Adoption of Improved Goat Husbandry Technologies in Jammu and Kashmir International Journal of Livestock Research 5(2) 54-63.

Shah I A, Hussain K and Shah M A (2015) Suggestions for Amelioration of Perceived Constraints in the Adoption of Improved Goat Husbandry Technologies in Jammu and Kashmir International Journal of Livestock Research 5(2) 54-63.

Singh M K, Dixit A K, Roy A K and Singh S K (2013) Goat Rearing: A Pathway for Sustainable Livelihood Security in Bundelkhand Region. Agricultural Economics Research Review 26: 79-88. Tanwar P S (2011) Constraints Perceived by Goat Keepers in Adoption of Goat Husbandry Practices in Semi-Arid Rajasthan, Journal of Community Mobilization and Sustainable Development 6 (1), 108-111.

\section{How to cite this article:}

Manoj Kumar Singh, Ramjee Gupta, P. K. Upadhyay, Dinesh Singh, Deepak Singh and Pankaj Rav. 2020. Constraints and Suggestions Faced by Goat Rearing Farmers in Mirzapur District of Uttar Pradesh. Int.J.Curr.Microbiol.App.Sci. 9(02): 1814-1819. doi: https://doi.org/10.20546/ijcmas.2020.902.207 